\title{
Student Moral Guidance Trough Islamic Education System on Pesantren Institution
}

\author{
Taufik Rizki Sista ${ }^{1}$, Abu Darda ${ }^{2}$, Muhammad Hudaya ${ }^{3}$, Safiruddin Al Baqi ${ }^{4}$, Dian Nasrul \\ Munif 5 \\ \{taufikrizki90@unida.gontor.ac.id ${ }^{1}$, abudarda_crb@yahoo.com ${ }^{2}$, \\ sarifuddinnabaqi@unida.gontor.ac.id $\left.{ }^{4}, \underline{\text { dianmunif123@gmail.com }}{ }^{5}\right\}$
}

University of Darussalam Gontor, Jl. Raya Siman km 6 Siman Ponorogo $0^{1,2,3,4,5}$

\begin{abstract}
Islamic education cannot be separated from moral guidance or moral education. Islamic boarding school institutions are the origin of Islamic education institution in Indonesia; the Pesantren institution is famous for its moral guidance for students. In the present day, there are two types of Pesantren institutions, the traditional and modern boarding schools, which both of them has its characteristics in the practice of moral guidance for its students. This research is qualitative research with case study models. The object of this research is Pondok Modern Darussalam Gontor campus 2 and Pondok Pesantren Darul Huda Mayak Ponorogo. The purpose of this study was to (1) find out how the Islamic Education models in Pondok Modern Darussalam Gontor campus 2 and Darul Huda Mayak Islamic Boarding School. (2) To find out how the excellent guidance process in each Pesantren institution. The research methodology uses Qualitative Research by Case Study Model. The results of this study are (1) the models of religious education Carried out at Pondok Modern Darussalam campus 2 Refers to the curriculum of Kulliyatul Muallimin Al-Islamiyah. The coverage of knowledge is $100 \%$ religion and $100 \%$ scientific knowledge, while the implementation of religious education in the Darul Huda Islamic boarding school Mayak Refers to the principle of Salafi Hadistah, which is the education curriculum with traditional salaf and contemporary educational methods. (2) The implementation of moral guidance activities at Pondok Modern Darussalam Gontor Campus 2 is to optimize the 24 -hour education process based on Islamic values.
\end{abstract}

Keywords: Islamic Education, Moral Education, Moral Guidance, Pesantren Institutions.

\section{Introduction}

Islamic education as a process of development of student potential aims to realize personal faith and fear to Allah, skilled, have a high work ethic noble character, independent and responsible for themselves, nation, and state and religion. [1] Islam wants the noble morality, because of the high morality will bring happiness for them self and for society in general [2]. In other words, the primary manners shown someone benefits are not only for themselves but also for others [3].

To achieve good moral required education morality, because education morality is a process of development, infusing, and teaching in humans to create and succeed the highest goal of Islam. Those goals are the happiness in the world and the afterlife, the perfection of the soul of society, got acceptance from Allah, security, grace, and receive pleasure that has been promised by God that apply to people who are kind and pious [4]. 
Boarding School/ Pesantren is a community, where religious scholars/ Head Master (Kyai), teachers (Ustadz), students (Santri) and administrators of the boarding school live together on one campus, based on the values of the Islamic religion complete with their norms and habits, which exclusively different from the general population surrounding them [5]. Pondok Pesantren is also a large family under the guidance of religious scholars (Kyai) helped by Ustadz, all signs that regulate the activities and limits of action: halal-haram, obligation-sunnah, good-bad and other departed from the Islam law. All activity is viewed and implemented as part of religious worship. In other words, all the events and activities of life have always been regarded with Islamic religious law [6].

As it grows boarding School divided into two based teaching methods are applied. The first is a boarding school Salafi that keep the original tradition of former teaching schools. The second is to apply the modern pesantren contemporary educational system in teaching.

Apart from that difference, pesantren with its function as an Islamic institution also serves as the broadcasting of Islam where the students are educated to be able to live in an atmosphere of shades of religious. Hence, the boarding school has a high level of integrity with the public surroundings and become good references/behaviour for the general public [7].

Based on the above presentation, we can conclude that the pesantren education agency upholds moral values embodied in Islamic education in general. The moral value can be implanted through typical Islamic religious education schools that have been arranged in the curriculum that patent.

In this study, researchers wanted to discover how the moral development in modern and Salafi schools, as well as how to apply the teachings of Islamic religious education in several pesantren in Ponorogo, and what factors supporting and hindering the process of implementation of Islamic religious education in the moral development of adolescents.

The purpose of this study was to determine the moral formation in modern boarding schools and the Salaf boarding school and knows the process of applying the teachings of Islamic religious education in coaching moral as well as factors that affect the process of passage of the curriculum of Islamic education in boarding schools.

\section{Literature Review}

The main text should be written using Times New Roman, 10pt, entirely justified. Italics can be used for emphasis, and bold typeset should be avoided.

\subsection{Islamic education}

The concept of Islamic education. Education can be reviewed from two perspectives. First, from the social community, education is a cultural inheritance from the older generation to the younger generation to live a sustainable society. Or in other words, people have the values and culture that wants to be channelled to the next generation so that the community's identity is maintained. On the other hand, when we viewed from the point of private education means the development of the potential of latent and hidden. Individuals are like the deep ocean full of pearls and a variety of fish, but not visible. It still in the towing. He needs to be fished and explored to become food for humans and jewellery [8].

Islamic education as a process of development of the creative potential of students aims to realize personal faith and fear of Allah, skilled, have a high work ethic noble character, 
independent and responsible for themselves, nation, and state and religion. In Islam, humans have an essential ability called "Fitrah". Epistemologically "Fitrah" means "nature of the origin, purity, talent, and disposition". The terminology, Muhammad al-Jurjani said that "Fitrah" is: The character is ready to accept Islam. Education is one's effort to develop the potential of monotheism to colour the quality of one's personal life [9].

The basics of the implementation of Islamic religious education. There are three basic implementations of Islamic education in Indonesia, namely [3]:

a. Juridical basis.

1) Basic principles of Pancasila, the first principle: Belief in God Almighty.

2) Constitutional basis in the UUD 45 in chapter XI of article 29, paragraphs 1 and 2

b. Enhancing the basic operations of MPR Decree No. IV / MPR / 1973 Religious basis.

The religious basis is derived from the teachings of Islam. Religious education is a commandment of God that manifests by worship to Him. In the Koran, there is a section showing the commandment [10].

c. Psychological basis.

The psychological aspect is fundamentally associated with the psychological aspects of people's lives.[11] It is based that in life, people both as individuals and as citizens are always confronted with things that ever made him uneasy and not at ease so require their foundation and lifeline. All people in this world requires an anvil, and active control is called religion [12].

\subsection{Moral Education in Islam.}

Islamic education as a process of development of the creative potential of students aims to realize personal faith and fear of Allah, skilled, have a high work ethic noble character, independent and responsible for themselves, nation, and state and religion. In Islam, humans have an essential ability called "Fitrah". Epistemologically " Fitrah" means "nature of the origin, purity, talent, and disposition" [13]. The terminology, Muhammad al-Jurjani said that "Fitrah" is: The character is ready to accept Islam. Education is one's effort to develop the potential of monotheism to colour the quality of one's personal life [14].

Islamic educational goals are ideals (ideals) containing values of Islam to be achieved in the process of Islamic education based on Islamic teachings gradually [15]. Based on the above understanding can be concluded that the Islamic Religious education is a process that is done to create fully human beings, faith, and fear of God Almighty and be able to realize its existence as a vicegerent of Allah on earth based on the teachings of the Qur'an and Al-Sunnah. So in this context means the creation of a perfect man after the education process ends[16], In the formulations containing the excellent values in the form of divinity, spirituality, humanitarian, social, personality, nationality, knowledge and skills. To prepare learners who needed strong leading values in the future [17].

Moral Education is a process of development, planting, and teaching in humans to create and success the highest goal of Islam. They are the happiness of two villages (world and hereafter), the perfection of the soul of society, gets Gods mercy, security, grace, and gets pleasure which had been promised by God that apply to people who are kind and pious [18]. 


\section{Results and Discussion}

\subsection{Moral Guidance in Modern Pesantren Institution (Darussalam Gontor Islamic Boarding School Campus 2.)}

\section{Main philosophy/principles applied in moral development in Pondok Modern Darussalam}

campus Gontor 2:

a. Al-Quran and al-Hadith.

b. Soul and philosophy of life Pondok Modern Gontor.

1) Sincerity.

The first cornerstone is used in students moral guidance in Gontor is the Spirit of sincerity. Sincerity mean is such as thankless task and doesn't expect any compensation.

2) Simplicity.

The soul of simplicity is a representation of humility, Tawadhu ', and avoid excessive lifestyle. Simplicity in the view of the founder of Gontor means moderation in lifestyle by the needs.

3) Self-reliance.

Self-reliance, in other words, is the meaning of independence. It is in Pondok Gontor was emphasized at the level of economic independence. It is intended that the cottage was not a burden on society and can give more to the community in terms of school fees in Pondok Modern Gontor as well as scholarships for students at the University of Darussalam Gontor.

4) Islamic brotherhood.

Islamic brotherhood in Gontor means that there is no difference between students in many aspects even base on economic background, ethnicity, ancestry, even countries. All students are treated equally without exception in academic and non-academic services.

5) Freedom.

The free will is a representation of human nature that always wants to be free in everything. It is a base of creation of the spirit of freedom in Pondok Modern Darussalam Gontor.

According to the verse above, it can be understood that humans have free will to be good and bad. Allah has provided direction and reward for those who want to do good or bad about the consequences of each.

Another philosophy in excellent guiding on teenagers/students on Darussalam Gontor campus 2 is a philosophy of life of Pondok Modern Darussalam Gontor, which are:

1) Live is Once, be Meaningful.

2) Bondo, Bahu, Pikir, Lek Perlu Sak Nyawane Pisan.

3) Be The Intellectual Ulama, Not Intellect Who Knows Religion,

c. The Synthesis of Life Values in Gontor

Educational foundation in Pesantren of Gontor is a synthesis or a combination of the excellence life values of some international institutions which applied by Gontor as the leading spirit of life in the implementation of education and teaching. Those institutions are:

1) Aligarh / India (for the modernity).

2) Al-Azhar / Egypt (for the independence of waqf).

3) Syanggit / Africa (for the philanthropy). 
4) Santi Niketan / India (for the peaceful).

The objective of moral guidance in Darussalam Gontor Islamic Boarding School campus 2. The primary objective of students' moral guidance in Gontor is generating the young Muslims generation of who want to struggle for the good of Ummah, have a simple lifestyle according to the life needs, self-sufficient in all aspects, have a strong sense of brotherhood among Muslims, and free to choose the way of life based on Islamic values and laws.

The methods of moral guidance in Pondok Modern Darussalam campus Gontor 2. To optimize the moral guidance process of students in Pondok Modern Gontor, then there are two methods applied are moral development through education and teaching, as well as through the regeneration process.

a. Education and teaching.

Education and teaching is a core activity in Pondok Modern Gontor. Through teaching and learning, Pesantren of Gontor transform the values to the students by formal class activity which taught the same knowledge of religious and science.

Educational activity held within 24 hours. The scope of Gontor education includes all the activities of Islamic daily life, the discipline of worship, military-like discipline, security and language, department assignment, and extracurricular activity.

The school's curriculum used is Kulliyatu-l-Mu'allimin Al-Islamiyya which adopted from Sumatra Thowalib schools, and that curriculum received an acknowledgment from the Ministry of Religion Indonesia.

The pesantren's curriculum is every principle of life on Gontor philosophers mentioned above, includes Panca Jiwa (Five Spirit of Gontor), Motto Pondok, Panca Jangka (Five LongTerm Plan), and Philosophy Life of Gontor. Any good guidance process shall go back to the foundation that has been determined above.

b. Regeneration.

One contributing factor is the existence of Pondok Modern Gontor is regeneration process. Regeneration aims to produce competent human in a specialized field which then can be beneficial to the pesantren. Regeneration is part of the education at the Pondok Gontor, but because it is a vital aspect for the existence of the Pesantren, the regeneration activities received special attention from the Head of the Pesantren.

Regeneration begins when the students assigned to some departments in the student's organization of Pondok Modern. Students are assigned to a particular department have to be responsible for his mission. Refuse the assignment, in Gontor environment, social violence that made a special black note for students who refuse the assignment. It might be a problem for a student who refuses the assignment in the future.

The implementation of the moral development process in Pondok Modern Darussalam Gontor campus 2. According to research findings, the outline of the process and teaching activities implemented as follows.

a. Curriculum applied in Pondok Modern Darussalam Gontor is curriculum Kulliyatul Mu'allimin Al-Islamiyah (curriculum focused on generating young teachers), with the lesson taught is $100 \%$ religious science and $100 \%$ technoscience.

b. The teaching process is held three times in one day. Morning lesson is starting at 07.00 until 12.30. The afternoon lessons begin at 02:00 noon until 03:00. Night lesson starting from 20:00 until 22:00.

c. The educational process held for 24 hours nonstop with various activities, made up situations, living environment, discipline, up to the dress code. 
d. Discipline lives in Pondok Gontor very tight and firm. Starting from the discipline of class, language discipline, daily life discipline, even to the discipline of worship. It aims to create a militant graduate, immoral and inherit the spirit and philosophy of life.

e. The punishment forms diverse according to the violations in the Pesantren Gontor. It is starting from balding, calling parents, moved to another branch campus of Gontor, suspended for one year, until the return of students to parents.

Many things found in research related regeneration system at the Pesantren Gontor are as follows:

a. Regeneration held with the assignment of students to the department of the student organization by the Principal of Institution.

b. The assignment of responsibilities aims to train students on the task at hand during one school year.

c. Another objective of the assignment is to train and educate students who are competent in specific areas were hereditary, so the manager does not lose the competent human resources in the field.

d. Pupils who are assigned to some department of a student organization will be penalized if he refuses the assignment, or deliberately making negligence in carrying out the task.

e. The negligence penalties are not much different from disciplinary punishment. Starting from balding, calling parents, moved to another campus of Gontor, suspended for one school year, until the return of students to parents.

\subsection{Moral Guidance at Traditional Pesantren Institution (Darul Huda Mayak Islamic Boarding School Ponorogo)}

The pillars of philosophy/principles used in the moral development of students at boarding Darul Huda Mayak

a. Al-Quran and al-Hadith

b. Salafi Haditha principle. Pesantren Darul Huda Mayak as traditional Pesantren, make the maximum effort to preserve the originality of the traditional Islamic education model. But because of the demands of the global era, Pesantren Darul Huda Mayak required to reform teaching model which capable of supporting learners to compete in this global era. Therefore, the pesantren Darul Huda Mayak apply the principle of Salafi Haditha, the traditional Islamic education with a mix of modern methods.

c. The aims in the moral development of the institution at boarding Darul Huda Mayak was Generating knowledge character of Muslim, charity and devoted fortified with good moral to religion and social empowerment.

Moral guidance methods at Darul Huda Mayak Islamic boarding school. To expedite the moral development in Darul Huda pesantren Mayak, the manager of pesantren apply some moral development of the following methods:

a. Education and teaching.

1) Darul Huda Islamic boarding school Mayak has two components of education, the first is Formal Education who follow the government curriculum, and the second is $\mathrm{MMH}$, or Madrasah Diniyah focused at studying the religious sciences and Pesantren culture.

2) All of the learning process as classroom and dormitory divided between men classroom and women classroom. 
3) Pesantren program includes Sorogan (lecturing by reading a traditional Islamic Studies books) and Wetonan held within a particular time. Sorogan program held after Maghrib until 19:30.

4) Not all students stay all day in the cottage, but there are leaving the house if the house is close to the location of the cottage.

5) MMH (Special Pesantren Education) curriculum using specialized curriculum while the learning process using the books of Pesantren Lirboyo and Ploso, such as books Imriti and Jurumiyah.

6) MMH level placement adjusted to the ability of students based in result from the entrance test. Tests include tests read and write Arabic, reading test of Kitab Kuning and the test write Pegon (Arabic letter with Java pronunciation). Extracurricular activities held on Friday. The activities include scouts, Khot / calligraphy and PMR (First Aid Training for Teenagers).

7) Students are educated to be able to follow the norms of society as well such as could lead Tahlilan, and help neighbors who need help.

b. Method of Salafi Haditha.

The application of Salafi Haditha method shows that the Darul Huda Mayak Islamic boarding school preserve the old methods and develop new and better methods of Islamic education.

This method is applied in Pondok Pesantren Darul Huda Mayak in the form of formal and nonformal education. Formal education includes junior high school (equivalent), Madrasah Aliyah (High School) and Madrasah Diniyah (MMH). While non-formal education held as lectures of traditional Islamic Studies books

By undertaking that method, Darul Huda Mayak Islamic boarding school students learn the science-religion of Islam as one part. Not only learn science in Islam as shariah, monotheism, and Sufism in order Tafaqquh Fiddiin but also learn the science of Islam that is generally such as physics, chemistry, biology and others in order Tafakkur Fii Kholqillah (Believes in God by thinking and observing to the creation). So with these methods will generate the students who have a strict faith, reliable and able to live in a society flexibly, compatible in this modern age.

The moral guidance process at Darul Huda Mayak Islamic boarding school. Based on the result found by the researchers, the process of moral guidance in Pesantren Darul Huda Mayak held by the following practices:

a. Internalization of values of the "Kitab Kuning" (Islamic Studies Traditional Books).

One of moral guidance process performed in Pesantren Darul Huda Mayak is examining the books of the Salaf (Kitab Kuning) by issuing values moral of the book, and follow the teachings of Kiai or Ustadz, and then will conduct the behavior of Tawadlu', sincerity, selfreliance, simplicity, and another moral character. If every time it appears the problem, both about irregularities in the social environment of the community, it will easy to solve through the advice of moral guidance which comes from the book of the Salaf, such as books Adabul Islamiyah, Ihya 'Ulumudiin, Ta'limul Muta'allim.

Kiai (The Principal of Boarding School) is the savior of his students from taking a step toward the possibility of error. "Kitab Kuning" mentioned above is the central pillar that contains several religious subject matter.

b. The habituation of Religious activities in Pesantren.

Darul Huda Mayak Islamic boarding school launched special programs calls Tafaqquh fiddin, the empowerment of students, and community development. According to the research in 
the field, the efforts which held by Pondok Pesantren Darul Huda Mayak on Tafaqquh Fiddin program through by:

1) Deep Learning Value of Islamic Studies books.

2) Memorizing Al-Quran and Hadist

3) Deep Pray of Shalat

Pesantren Darul Huda Mayak, aside from known as Tafaqquh Fiddin (Deep Religious Learning) institution, those institutions develop and synthesize other aspects of students' empowerment. Such as empowering the student's talents with Calligraphy art skills and Musabaqah Qira'atil Qutub (Reading Islamic Traditional Book Competition). To keep their mind busy, preserve the distinctiveness and excellence of Pesantren and avoid sexual deviance on students.

\section{CONCLUSION}

Based on the research results, the noted conclusions are described in the table below:

Table 1. The Main Concepts of moral Guidance in Pesantren Institutions

\begin{tabular}{|c|c|c|}
\hline & Modern Pesantren Institution & $\begin{array}{l}\text { Traditional Pesantren } \\
\text { Institution }\end{array}$ \\
\hline $\begin{array}{c}\text { Main } \\
\text { philosophy/principles }\end{array}$ & $\begin{array}{l}\text { 1. Al-Quran and Al-Hadith, } \\
\text { 2. The Life Philosophy of Pondok } \\
\text { Modern Gontor } \\
\text { 3. Synthesis value of Gontor }\end{array}$ & $\begin{array}{l}\text { 1. Al-Quran and Al- } \\
\text { Hadith } \\
\text { 2. Salafi } \\
\text { Approach }\end{array}$ \\
\hline $\begin{array}{l}\text { The objective of } \\
\text { moral guidance }\end{array}$ & $\begin{array}{l}\text { The generation of Muslims with: } \\
\text { 1. A will to struggle for the good of } \\
\text { Ummah. } \\
\text { 2. Simple lifestyle. } \\
\text { 3. Self-sufficient. } \\
\text { 4. The sense of brotherhood. } \\
\text { 5. Free to choose the way of life }\end{array}$ & $\begin{array}{l}\text { The generation of } \\
\text { Muslims with: } \\
\text { 1. Knowledgeable } \\
\text { character, } \\
\text { 2. Be charity } \\
\text { 3. Fear of good. }\end{array}$ \\
\hline $\begin{array}{l}\text { The methods used in } \\
\text { moral guidance }\end{array}$ & $\begin{array}{l}\text { 1. Comprehensive educating and } \\
\text { teaching } \\
\text { 2. regeneration of Human resources }\end{array}$ & $\begin{array}{l}\text { 1. } \begin{array}{l}\text { Education } \\
\text { teaching }\end{array} \\
\text { 2. } \begin{array}{l}\text { Salafi } \\
\text { method. }\end{array}\end{array}$ \\
\hline $\begin{array}{l}\text { How moral guidance } \\
\text { is implemented }\end{array}$ & $\begin{array}{l}\text { By optimizing the educational process } \\
\text { for } 24 \text { hours based on the daily } \\
\text { discipline and curriculum of pesantren }\end{array}$ & $\begin{array}{l}\text { By internalization of the } \\
\text { values of the Kitab } \\
\text { Kuning (traditional } \\
\text { Islamic studies books) in } \\
\text { the daily lives days and } \\
\text { habituation religious } \\
\text { activities in boarding } \\
\text { schools }\end{array}$ \\
\hline
\end{tabular}


In some cases, this research is less able to describe more detailed information and internal information on the institution. Like problems in adolescent moral development in each institution, how to solve the problem of diversity in each boarding school, both modern and traditional. The information obtained by researchers regarding this matter is very little, so it cannot be appropriately described in this paper.

However, the results of the studies above are not intended to compare traditional Pesantren institution and modern pesantren institution, so that critics are not raised regarding the students' good guidance method. Significant differences may be seen in the managerial patterns of each institution so that the advantages and disadvantages of each institutional pattern will emerge. So in further research, researchers will discuss related with the patterns/models of institutional management in traditional Islamic boarding schools and modern Islamic boarding schools.

\section{References}

[1] H. M. Baidlawi, "Modernisasi Pendidikan Islam ( Telaah Atas Pembaharuan Pendidikan di Pesantren)," Tadris, vol. 1, no. 2, pp. 154-167, 2006.

[2] T. R. Sista, "PERKEMBANGAN MODERNISASI SISTEM PENDIDIKAN ISLAM DI INDONESIA MELALUI GAGASAN ISLAMISASI ILMU PENGETAHUAN ( THE DEVELOPMENT OF ISLAMIC EDUCATION SYSTEM MODERNIZATION IN INDONESIA TROUGH THE IDEAS OF KNOWLEDGE ISLAMIZATION )," J. Ilm. Pesantren, vol. 5, no. 1, pp. 583-594, 2019.

[3] Arif Billah, "Pendidikan Karakter Untuk Anak Usia Dini Dalam Perspektif Islam dan Implementasinya Dalam Materi Sains,” At-Ta'dibTarbiyah, vol. I, no. 2, pp. 243-272, 2016.

[4] T. R. Sista, "Implementasi Pendidikan Agama Islam Dalam Pembinaan Moral Remaja ( Studi Kasus di Pesantren Modern Muadalah dan Pesantren Salaf/ Tradisional )," At-Ta'dib, vol. 13, no. 2, pp. 154-167, 2018.

[5] I. Syafei, "Pondok Pesantren: Lembaga Pendidikan Pembentukan Karakter," J. Pendidik. Islam Al Tadzkiyyah, vol. 8, pp. 85-103, 2017.

[6] M. M. Ulum, "Konsep Pendidikan Anak Menurut Al-Ghazali dan Relevansinya Dengan Arah dan Tujuan Pendidikan Nasional di Indonesia," At-Ta'dib, vol. 4, no. 2, pp. 235-247, 2009.

[7] M. Hasan, "Inovasi Dan Modernisasi Pendidikan Pondok Pesantren," KARSA J. Sos. dan Budaya Keislam., vol. 23, no. 2, pp. 295-305, 2015.

[8] Shobahussurur, "Pembaruan Pendidikan Islam Perspektif Hamka," Tsaqafah, vol. 5, no. 1, pp. 79-96, 2015.

[9] Alhamuddin, "Pendidikan Islam Modern ala Trimurti Pondok Modern Darussalam Gontor," AtTa'dib, vol. 03, no. Desember, pp. 203-231, 2005.

[10] N. H. Nasution, “Metode Dakwah Dalam Membentuk Akhlak Mahmudah Remaja,” Wardah, vol. 23, no. 1, pp. 163-177, 2011.

[11] K. Odit-dookhan, "ATTITUDE TOWARDS E-LEARNING: THE CASE OF MAURITIAN STUDENTS IN PUBLIC TEIS,” vol. 4, no. 3, pp. 628-643, 2018.

[12] D. Lestari and Partini, "Hubungan Antara Penalaran Moral Dengan Perilaku Prososial Pada Remaja," J. Indig., vol. 13, no. 2, pp. 41-46, 2015.

[13] A. Budiman and T. R. Sista, "Pengaruh Pemahaman Ajaran Agama Islam Terhadap Kualitas Moral Remaja," At-Ta'dib, vol. 12, no. 2, pp. 121-136, 2017. 
[14] A. Yameen, I. Campus, and L. Iftikhar, "IMPACT OF RELIGIOUS ORIENTATION AND LIFE SATISFACTION ON DEATH ANXIETY AMONG,” vol. 4, no. 2, pp. 477-485, 2018.

[15] Subur, "Peran Pendidikan Agama Islam Dalam Perkembangan Jiwa Remaja," Tarbiyatuna, vol. 7, no. 2, pp. 167-185, 2016.

[16] Kastolani, "Ibadah Ritual Dalam Menanamkan Akhlak Remaja," Inject, vol. 01, no. 02, pp. 127$144,2016$.

[17] D. Herman, "Remaja Dalam Perspektif Pendidikan Islam,” Al-Izzah, vol. 10, no. 1, pp. 54-70, 2015.

[18] U. A. Yusuf, "Manajemen Pendidikan Akhlak Menurut 'Abdullah Nasih Ulwan ( Studi Kitab TARBIYAH Al- Aulad Fi Al - Islam )," Edukasi Pendidik. Islam, vol. 06, no. 12, pp. 63-79, 2017. 